The University of Maine

\title{
DigitalCommons@UMaine
}

Marine Sciences Faculty Scholarship

School of Marine Sciences

$1-1-1981$

\section{Remotely Operated Trap for Capture of Territorial Fishes}

D. Smith

Irv Kornfield

University of Maine - Main, irvk@maine.edu

B. Goodwin

Follow this and additional works at: https://digitalcommons.library.umaine.edu/sms_facpub

\section{Repository Citation}

Smith, D.; Kornfield, Irv; and Goodwin, B., "Remotely Operated Trap for Capture of Territorial Fishes" (1981). Marine Sciences Faculty Scholarship. 105.

https://digitalcommons.library.umaine.edu/sms_facpub/105

This Other is brought to you for free and open access by DigitalCommons@UMaine. It has been accepted for inclusion in Marine Sciences Faculty Scholarship by an authorized administrator of DigitalCommons@UMaine. For more information, please contact um.library.technical.services@maine.edu. 
fresh and compound foods. Fish. Invest. Ser. II (London). 27(7):1-16.

Hartmann, M., F.G. Merdem, R. Kuhn, and H.J. Beihlig. 1947. Uber die Gynogamone der Regenbogenforelle [Concerning the gynogamone in rainbow trout]. Naturwissenschaft 34:25-26.

Hubbs, C., and L. Stavenhagen. 1958. Effects of maternal carotenoid deficiency on the viability of darter (Osteichthyes) offspring. Physiol. Zool. 31:280-283.

Johnson, F. C. 1979. The antioxidant vitamins. CRC Crit. Rev. Food Sci. Nutr. 10(3):217-309.

Kirk, R. G. 1972. Anomalous growth of young plaice (Pleuronectes platessa) on diets of live, frozen and freezedried Lumbricillus rivalis Levinsen. Aquaculture 1(1):35-37.

Krinsky, N. I. 1971. Carotenoid function. Pages 669-716 in O. Isler, ed. Carotenoids. Birkhauser Verlag, Basel.

Lam, T. J., Y. Nagahama, K. Chan, and W. S. Hoar. 1978. Overripe eggs and postovulatory corpora lutea in the three spine stickleback Gasterosteus aculeatus L., form trachurus. Can. J. Zool. 56:2029-2036.

Land, E. J. 1975. Photochemistry of polyenes. Photochem. Photobiol. 22:286-288.

Lewis, N. F., M. S. Ramamurthy, and U. S. Kumta. 1979. Storage stability of proteins and pigment in freeze-dried shrimp (Penaeus indicus). Die Fleischwirtsch. (January) 1:77-78, 102-104.

Lotthammer, K. H. 1978. Importance of $\beta$-carotene for bovine fertility - original researches. Pages 5-44 in Proc. Roche Symposium on importance of $\beta$-carotene for bovine fertility. London. October 1978.

, L. Ahlswede, and H. Meyer. 1976. Investigations on a specific vitamin $A$ - unrelated effect of $\beta$-carotene on the fertility of cattle. 2. Further clinical findings and conception rates (experiment III). Deutsche Tierarztl. Wochenschr. 83:353-358.

Meyer, H., L. Ahlswede, and K. H. Lotthammer. 1975. Investigations on a specific vitamin A-unrelated effect of $\beta$-carotene on the fertility of cattle. 1. Methods, body development and ovary function. Deutsche Tierarztl. Wochenschr. 82:444-449.

Meyers, S. P. 1977. Using crustacean meals and carotenoid fortified diets. Feedstuffs (9 May) 38:26-27.

Mikulin, A. Y., and S. G. Soin. 1975. The functional significance of carotenoids in the embryonic development of teleosts. J. Ichthyol. (Engl. transl. Vopr. Ikhtiol.) 15(5):749-759.

Nilsson, R., G. Swanbeck, and G. Wennersten. 1975. Primary mechanisms of erythrocyte photolysis induced by biological sensitizers and phototoxic drugs. Photochem. Photobiol. 22:183-186.

Patton, S., and J. J. Kelly, 1980. Carotene in bovine milk fat globules: Observations on origin and high content in tissue mitochondria. Lipids 15(1):33-38.

Sakai, K., M. Nomura, F. Takashima, and H. Oto. 1975. The overripening phenomenon of rainbow trout. II. Changes in the percentage of eyed eggs, hatching rate and incidence of abnormal alevins during the process of overripening. Bull. Jpn. Soc. Sci. Fish. 41:855-860.

Schams, D., B. Hoffmann, K. H. Lotthammer, and L. Ahlswede. 1977. Investigations on a specific vitamin A -unrelated effect of $\beta$-carotene on the fertility of cattle. 4. Specific effects on hormonal parameters during the estrous cycle. Deutsche Tierarztl. Wochenschr. 84:307-310.

Simpson, K. L. 1979. Use of carotenoids in fish feeds. In J. E. Halver and K. Tiews, eds. Vol. II, Finfish nutrition and fish feed. Tech. Proc. World Symp., Hamburg, 20-23 June 1978. Heenemann Publ., Berlin.

Steven, D. M. 1949. Studies on animal carotenoids -1 . Carotenoids of the brown trout (Salmo trutta Linn.). J. Exp. Biol. 25:369-387.

Yamashoji, J., H. Yoshida, and G. Kajimoto. 1979. Photooxidation of linoleic acid by ultraviolet light and effect of superoxide anion quencher. Agric. Biol. Chem. 43(6): $1249-1254$.

Accepted 15 June 1981

\section{Remotely Operated Trap for Capture of Territorial Fishes}

In a study of assortative mating in a polymorphic species of cichlid, attempts to capture individual pairs of spawning fish by using spear guns and hand nets proved unsuccessful. Capture was necessary because morphs could be unequivocally identified only by internal examination. We describe a relatively simple device for the capture of territorial fish that proved efficient in field application.

Males of this undescribed territorial Mexican
Cichlasoma species are extremely wary and generally defend territories bordering on dense vegetative cover into which they can readily escape. Conversely, females can easily be captured because they exhibit strong maternal behavior and closely guard their offspring.

During a previous study, we observed that automobile tires placed in open water bordering established male territories were quickly incorporated into the territory. Spawning usually occurred on the inside 
wall of the tire or in a pit dug in the enclosed substrate. We concluded, on the basis of these observations, that a tire trap could be designed that would capture pairs in the act of spawning.

The trap (Fig. 1) consists of a remotely operated trigger mechanism attached to a tire covered with 1.9-cm (3/4-in.) nylon netting. The bottom of the tire is completely enclosed with netting secured by a canvas belt around the circumference of the tire. A metal hook with a support arm is attached to the netting on top. This assembly engages the trigger lever at one end and an elastic shock cord at the other. The shock cord provides the driving force to rapidly draw the netting taut across the tire well (Fig. 1C). A trip line 4-5 $\mathrm{m}$ long tied to the trigger lever releases the hook assembly. While the trap is being armed, by drawing around the shock cord, a metal pin is inserted through the fully depressed lever to rest on the trigger support block, thereby preventing misfiring. Trapped fish can be removed and transferred to holding bags under water or they can be recovered at the surface or on shore by floating the trap.

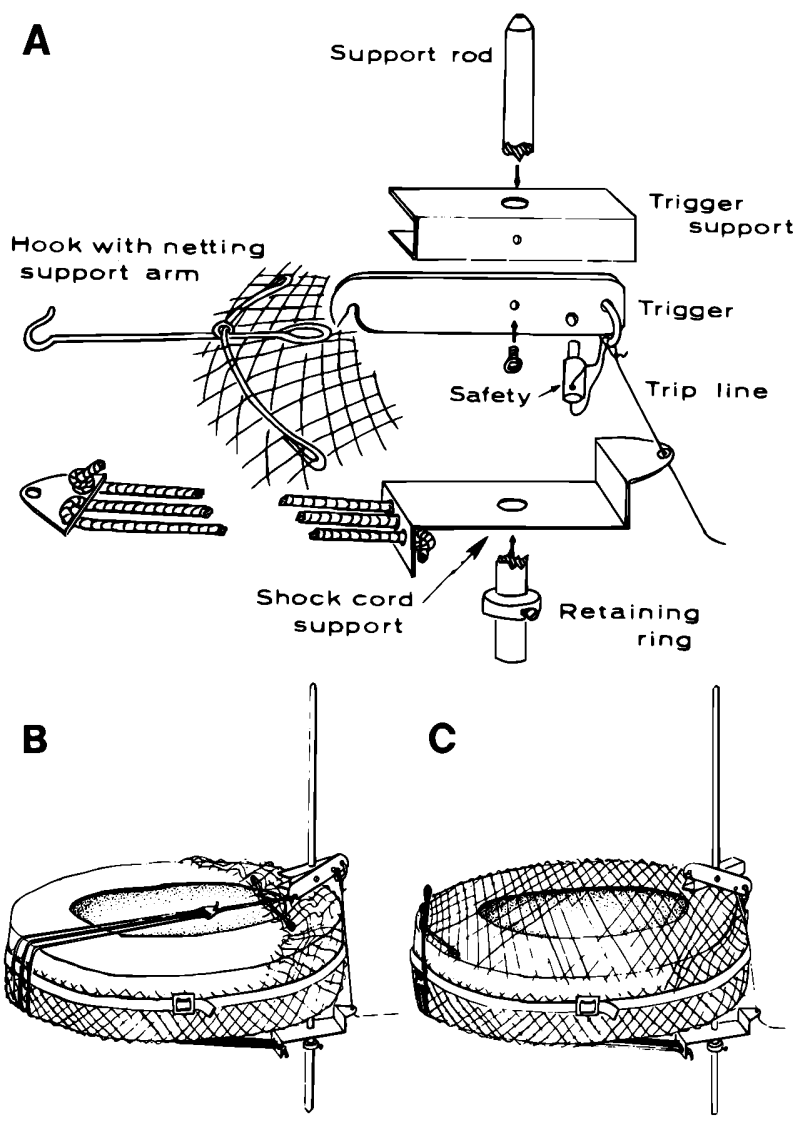

Fig. 1. Observer-operated tire trap: $A$, schematic of triggering mechanism and component parts; $B$, trap in armed position; $C$, trap after being activated.
In July 1980, we set out 20 tire traps in a variety of habitats in freshwater ponds at Cuatro Cienegas, Mexico. All tires in favorable habitats were colonized by mature males, and during the study period eight pairs of mating cichlids were collected by this method.

Many fish traps have been designed for operation in specific types of habitats or for capture of selected species (McClain and Manion 1967; Marlborough 1969; Lawler 1973; Collins 1975; Bloom 1976; Graser 1978). However, such traps operate in a passive manner to collect all fish that swim or drift into them. By contrast, the tire trap captures only specific individuals of interest. The trap we describe can be used effectively for live capture of a number of territorial marine and freshwater species. Further, by varying netting mesh size, a degree of species selectively can be obtained. When placed in clear stream habitats, the traps can easily be monitored and operated by landbased observers.

\section{Acknowledgments}

Financial support for this research was provided by NSF Grant DEB 78-24074 and Earthwatch, The Center for Field Research, Belmont, Massachusetts.

\section{References}

Bloom, A.M. 1976. Evaluation of minnow traps for estimating populations of juvenile Coho salmon and Dolly Varden. Prog. Fish-Cult. 38(2):99-101.

Collins, J.J. 1975. An emergent fish trap for lake spawning salmonines and coregonines. Prog. Fish-Cult. 37(3): 140-142.

Graser, L.F. 1978. Flow-through collection bucket for larval fish. Prog. Fish-Cult. 40(2):78-79.

Lawler, A.R. 1973. A non-baited fish trap for shallow water. Prog. Fish-Cult. 35(4):237-238.

Marlborough, D. 1969. A cheap and easily constructed fish trap. Prog. Fish-Cult. 31(2):117.

McClain, A.L., and P.J. Manion. 1967. An all-season trap for downstream migrating fish and other aquatic organisms. Prog. Fish-Cult. 29(2):114-117.

- David Smith and Irv Kornfield, Migratory Fish Research Institute and Department of Zoology, University of Maine at Orono, and Bernard Goodwin, Department of Physics, University of Maine at Orono, Orono 04469. 